\title{
Metabolic changes induced by pre-administration of L-alanyl-glutamine and Omega-3 in Wistar rats subjected to sepsis ${ }^{1}$
}

\author{
Alterações metabólicas induzidas pela pré-administração de L-alanil-glutamina e ômega-3 em \\ ratos Wistar submetidos à sepse
}

\author{
José Ivamberg Nobre de Sena ${ }^{\mathrm{I}}$, Sérgio Botelho Guimarães ${ }^{\mathrm{II}}$, Paulo Roberto Leitão de Vasconcelos ${ }^{\mathrm{II}}$ \\ ${ }^{\mathrm{I}}$ Fellow PhD Degree, Department of Surgery, Postgraduate Program, UFC, Ceara, Brazil.

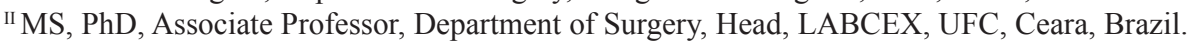 \\ ${ }^{\text {III }} \mathrm{PhD}$, Associate Professor, Department of Surgery and Coordinator, Postgraduate Program, UFC, Ceara, Brazil.
}

\begin{abstract}
Purpose: To evaluate the metabolic changes induced by pre-administration of L-alanyl-glutamine (L-Ala-Gln) and omega-3 ( $\omega$-3) in rats subjected to sepsis. Methods: Eighteen male Wistar rats were randomized into three groups $(\mathrm{n}=6)$ and treated with saline (group Control-G-1), L-Ala-Gln (0.75 mg / kg, G-2) or $\omega-3$ (0.2 g/kg, G-3 ) administered intravenously 3,2 and 1 day and 30 minutes before induction of sepsis. Samples (blood, striated muscle and liver) were collected 48 hours after induction of sepsis, to measure the concentrations of metabolites (pyruvate, lactate, glucose and ketone bodies. Results: There was a significant increase in muscle glycolysis and gluconeogenesis in the liver in rats treated with L-Ala-Gln and $\omega-3$, compared to the control group, 48 hours after induction of sepsis. Conclusion: Pre-administration of L-Ala-Gln or $\omega-3$ to rats subjected to sepsis resulted in similar metabolic changes, by rising glycolysis in peripheral tissues and stimulating hepatic gluconeogenesis and ketogenesis, resulting in increased energy supply to septic rats.
\end{abstract}

Key words: Sepsis. Metabolism. Glutamine. Fatty Acids, Omega-3. Rats.

\section{RESUMO}

Objetivo: Avaliar as alterações metabólicas induzidas pela pré-administração de L-alanil-glutamina (L-Ala-Gln) e ômega-3 ( $\omega$-3) em ratos Wistar submetidos à sepse. Métodos: Dezoito ratos machos Wistar, randomizados em três grupos iguais ( $\mathrm{n}=6$ ) e tratados com solução salina (grupo Controle-G-1), L-Ala-Gln $(0,75 \mathrm{mg} / \mathrm{Kg})$ ou $\omega-3(0,2 \mathrm{~g} / \mathrm{Kg})$ por via endovenosa administrados 3,2 e 1 dia e 30 minutos antes da indução do estado de sepse. Amostras (sangue, músculo estriado e fígado) foram coletadas 48 horas após indução da sepse, para dosagem das concentrações de metabólitos (piruvato, lactato, glicose e corpos cetônicos). Resultados: Houve aumento significante da glicólise no músculo e da gliconeogênese no fígado nos ratos tratados com L-Ala-Gln e $\omega$-3, comparados ao controle, 48 horas após a indução da sepse. Conclusão: A pré-administração de L-Ala-Gln ou $\omega-3$ em ratos submetidos à sepse resultou em alterações metabólicas semelhantes, com aumento da glicólise nos tecidos periféricos e da gliconeogênese hepática e cetogênese, aumentando a oferta de energia disponível.

Descritores: Sepse. Metabolismo. Glutamina. Ácidos Graxos Ômega-3. Ratos.

${ }^{1}$ Research performed at the Experimental Surgery Research Laboratory (LABCEX), Department of Surgery, Federal University of Ceara (UFC), Brazil.

\section{Introduction}

Studies have shown that the metabolic response is similar in different circumstances of aggression to the body such as a musculoskeletal trauma, burns, infection and sepsis. The duration and magnitude of this response are proportional to the level of injury severity, nutritional status, sex and age of individuals, their hormonal response and even the ambient temperature ${ }^{1,2}$. In order to provide an appropriate metabolic response the body requires a sustainable energy supply. The energy substrates used directly are glucose, which occupies the central role of the whole body metabolism, fatty acids, amino acids, lactate, derived from anaerobic glycolysis, pyruvate, and the ketone bodies ${ }^{3,4}$.

In recent years, there has been considerable progress in the field of sepsis ${ }^{5,6}$. Studies In humans and in experimental animals has shown important changes in liver metabolism, including changes in gluconeogenesis, decreased ketogenesis, hyperglycemia, and hiperlactacemia increased insulin resistance ${ }^{5,7}$.

Both L-alanyl-glutamine (L-Ala-Gln) and omega-3 polyunsaturated oil $(\omega-3)$ have been identified as participants and agents acting directly on metabolic processes of amino acids. Their anti-inflammatory and immunomodulatory properties have been demonstrated in several studies in recent years ${ }^{8-10}$. 
Glutamine (Gln) is the most abundant free amino acid in the human body. Gln plays an important role in amino acid metabolism. The transport of nitrogen from skeletal muscle into the intestines (serving as an energy substrate) to the liver (in case of starvation or injury) to the kidneys and in cell proliferation of the immune system ${ }^{11}$. Omega $(\omega-3)$ is a family of polyunsaturated fatty acids found in some seeds, some fish and milk. They are constituents of all cell membranes and essential processes of cell regeneration. Highest concentration is found in nervous tissue. Several studies have shown that fatty acids $\omega-3$ are immunomodulatory agents and anti-inflammatory, antithrombotic, and antiarrhythmic drugs. Their ability in reducing blood lipids and promoting vasodilatation have important therapeutic effects in several diseases that are associated with an inflammatory component, sepsis included ${ }^{12-14}$.

Not all metabolic aspects of sepsis are clear. Therefore further clarifications are necessary in relation to various aspects of metabolism in the host and the reaction to external aggressions.

\section{Methods}

Approval for experimental use of laboratory animals was obtained from the Commission of Ethics in Animal Research, Federal University of Ceara. Throughout the study, the guidelines of the Brazilian Animal Experiments College (COBEA) were followed. The animals were housed in groups of five in plastic cages $(39 \times 33 \times 16 \mathrm{~cm})$ at controlled temperature $\left(22 \pm 1^{\circ} \mathrm{C}\right)$ on a $12 \mathrm{~h} \mathrm{light/dark} \mathrm{cycle} \mathrm{with} \mathrm{constant} \mathrm{air} \mathrm{exchange} \mathrm{and} \mathrm{free} \mathrm{access} \mathrm{to}$ food and water. During the course of experiment water and food were provided ad libitum.

Eighteen male Wistar rats $(350-450 \mathrm{~g})$ were randomized into three groups $(\mathrm{n}=6)$ and treated with saline (group ControlG-1), L-Ala-Gln (0.75 mg / kg , G-2) or $\omega-3$ (0.2 g / kg, G-3 ) administered intravenously (Figure 1) 3, 2 and 1 day and 30 minutes before induction of sepsis. Samples (blood, striated muscle and liver) were collected 48 hours after induction of sepsis, to measure the concentrations of metabolites (pyruvate, lactate, glucose and ketone bodies).

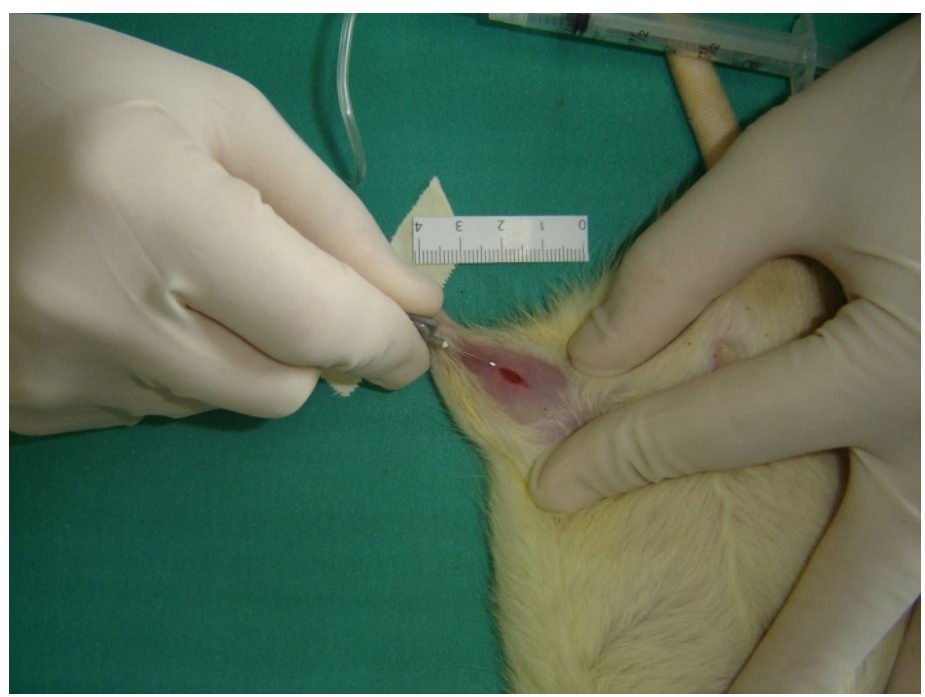

FIGURE 1 - Insertion of intravenous plastic catheter for nutraceuticals infusion
Sepsis was developed according to previously established model $^{1,15}$. Anesthetized (diethyl ether) rats were subjected to a 3 inches long longitudinal laparotomy. After proper milking the fecal content, mobilization and isolation of an intestinal segment, blood supply to the distal cecum was interrupted by ligation and section of its meso. Next, the cecum was ligated circumferentially with a 3-0 cotton suture and was punctured with a gauge 21 needle in its anti-mesenteric surface (Figures 2 and 3). The viscera were repositioned and the abdominal cavity was closed in two planes using 3-0 cotton suture. With this procedure, the animals were induced to develop peritonitis followed by $\operatorname{sepsis}^{16}$ (Figure 4).

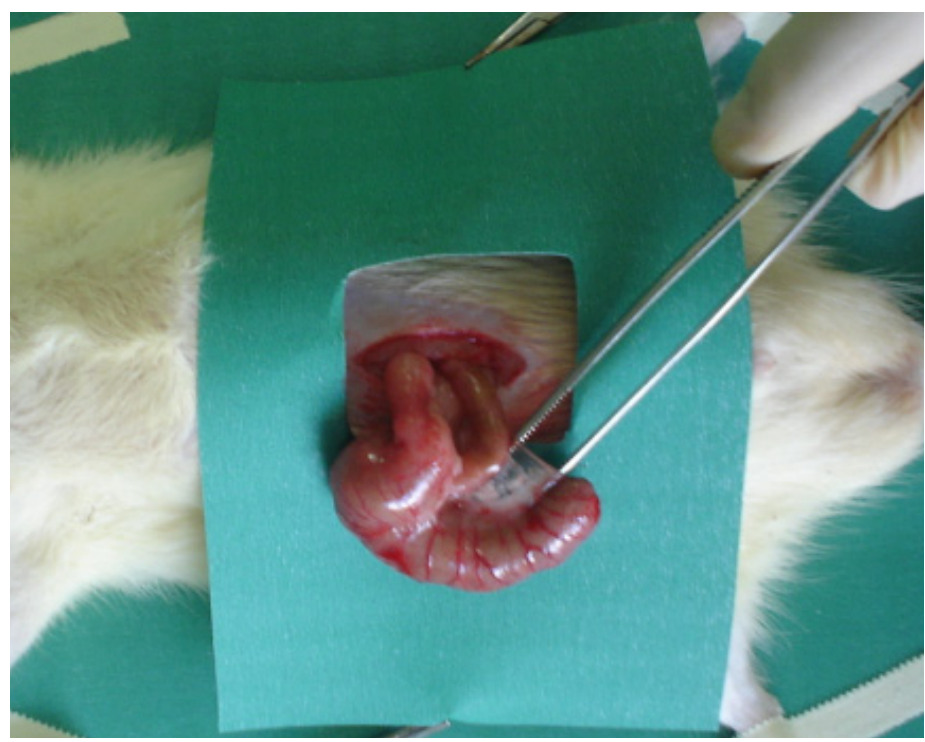

FIGURE 2 - Laparotomy incision and exposure of the intestinal viscera

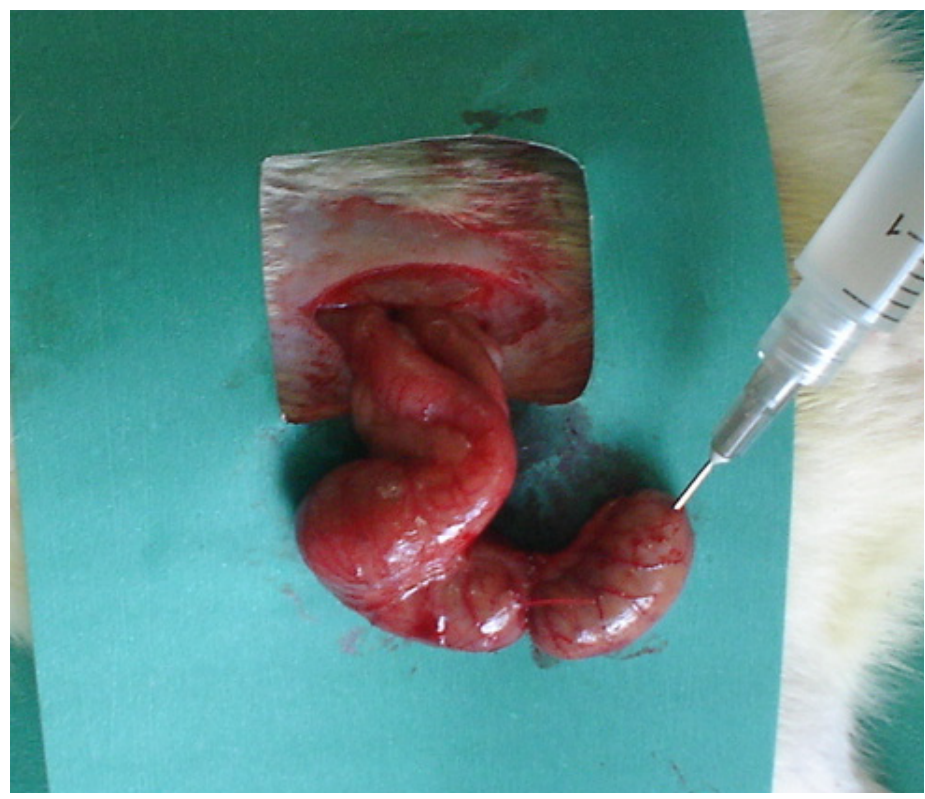

FIGURE 3 - Cecum ligation and distal needle puncture 


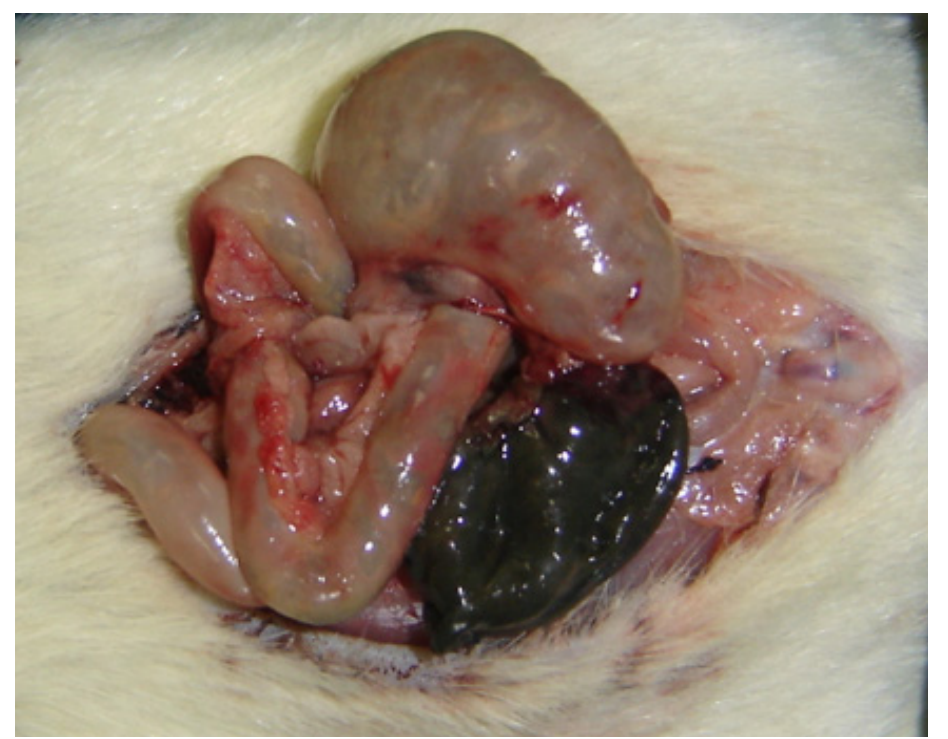

FIGURE 4 - Diffuse peritonitis following cecum ligation and distal needle puncture

\section{Biochemical analysis}

Samples (blood, striated muscle and liver) were collected from the inferior vena cava 48 hours after induction of sepsis. Pyruvate, lactate, glucose and ketone bodies concentrations were assayed in blood striated muscle and liver samples according to biochemical methods published elsewhere ${ }^{17-20}$.

\section{Statistical analysis}

Graphpad Prism 4.0 (GraphPad Software, San Diego California USA, www.graphpad.com) was used for computation and statistical analysis. All results were expressed as mean \pm SEM. All data were tested for distribution (Kolmorogov-Smirnov test with Dallal-Wilkinson-Lilliefor $P$ value). Mann Whitney test was used for comparisons between control and experiment groups. $P$ values of less than 0.05 were considered significant.

\section{Results}

The results are presented in Tables 1-4.

TABLE 1 - Mean pyruvate concentrations in the blood $(\mu \mathrm{mol} / \mathrm{ml})$ and tissue $(\mathrm{mol} / \mathrm{g})$ in groups $\mathrm{G} 1$ treated with saline, G2 - treated with L-Ala-Gln and G3 - treated with Omega-3, 48 hours after sepsis induction

\begin{tabular}{lccc}
\hline PYRUVATE & Nutraceutical/control & Concentration & $\boldsymbol{p}$ value \\
\hline Liver & Saline & $0.042 \pm 0.008$ & $n s$ \\
& L-Ala-Gln & $0.265 \pm 0.037$ & $\mathrm{p}<0.01$ \\
& Omega-3 & $0.298 \pm 0.086$ & $\mathrm{p}<0.01$ \\
Blood & Saline & $0.058 \pm 0.015$ & $n s$ \\
& L-Ala-Gln & $0.493 \pm 0.048$ & $\mathrm{p}<0.01$ \\
& Omega-3 & $0.089 \pm 0.013$ & $n s$ \\
Striated muscle & Salina & $0.021 \pm 0.006$ & $n s$ \\
& L-Ala-Gln & $0.201 \pm 0.079$ & $\mathrm{p}<0.05$ \\
& Omega-3 & $0.151 \pm 0.031$ & $\mathrm{p}<0.05$ \\
\hline
\end{tabular}

Values expressed as Mean \pm SEM. $p<0.05$, L_Ala-Gln and Omega-3 groups are significantly different from control group by Mann-Wittney test. $n s=$ non-significant 
TABLE 2 - Mean lactate concentrations in the blood $(\mu \mathrm{mol} / \mathrm{ml})$ and tissue $(\mathrm{mol} / \mathrm{g})$ in groups $\mathrm{G} 1$ treated with saline, G2 - treated with L-Ala-Gln and G3 - treated with Omega-3, 48 hours after sepsis induction

\begin{tabular}{lccc}
\hline LACTATE & Nutraceutical/control & Concentration & $p$ value \\
\hline Liver & Saline & $0.851 \pm 0.080$ & $n s$ \\
& L-Ala-Gln & $3.420 \pm 0.219$ & $p<0.01$ \\
& Omega-3 & $10.700 \pm 0.880$ & $p<0.05$ \\
Blood & Saline & $1.050 \pm 0.304$ & $n s$ \\
& L-Ala-Gln & $7.080 \pm 0.993$ & $p<0.01$ \\
Striated muscle & Omega-3 & $2.230 \pm 0.128$ & $n s$ \\
& Salina & $0.897 \pm 0,091$ & $n s$ \\
& L-Ala-Gln & $6.070 \pm 1.220$ & $p<0.01$ \\
& Omega-3 & $12.800 \pm 1.160$ & $p<0.05$ \\
\hline
\end{tabular}

Values expressed as Mean \pm SEM. $p<0.01, p<0.05$, L_Ala-Gln and Omega-3 groups are significantly different from control group by Mann-Wittney test. $\overline{n s}=$ non-significant

TABLE 3 - Mean glucose concentrations in the blood $(\mu \mathrm{mol} / \mathrm{ml})$ and tissue $(\mathrm{mol} / \mathrm{g})$ in groups $\mathrm{G} 1$ treated with saline, G2 - treated with L-Ala-Gln and G3 - treated with Omega-3, 48 hours after sepsis induction

\begin{tabular}{lccc}
\hline GLUCOSE & Nutraceutical/control & Concentration & $p$ value \\
\hline Liver & Saline & $2.220 \pm 0.459$ & $n s$ \\
& L-Ala-Gln & $12.300 \pm 3.360$ & $p<0.01$ \\
& Omega-3 & $13.000 \pm 2.200$ & $p<0.05$ \\
Blood & Saline & $1.430 \pm 0.335$ & $n s$ \\
& L-Ala-Gln & $5.440 \pm 1.050$ & $p<0.01$ \\
& Omega-3 & $2.370 \pm 0.169$ & $n s$ \\
Striated muscle & Salina & $0.434 \pm 0.038$ & $n s$ \\
& L-Ala-Gln & $0.090 \pm 0.041$ & $p<0.01$ \\
& Omega-3 & $2.310 \pm 0.806$ & $n s$ \\
\hline
\end{tabular}

Values expressed as Mean \pm SEM. $p<0.01, p<0.05$, L_Ala-Gln and Omega-3 groups are significantly different from control group by Mann-Wittney test. $n s=$ non-significant 
TABLE 4 - Mean ketone bodies concentrations in the blood $(\mu \mathrm{mol} / \mathrm{ml})$ and tissue $(\mathrm{mol} / \mathrm{g})$ in groups G1 - treated with saline, G2 - treated with L-Ala-Gln and G3 - treated with Omega-3, 48 hours after sepsis induction

\begin{tabular}{lccc}
\hline KETONE BODIES & Nutraceutical/control & Concentration & $p$ value \\
\hline Liver & Saline & $0.074 \pm 0.009$ & \\
& L-Ala-GIn & $1.303 \pm 0.302$ & $p<0.05$ \\
& Omega-3 & $1.060 \pm 0.245$ & $p<0.001$ \\
Blood & Saline & $0.114 \pm 0.027$ & \\
& L-Ala-Gln & $1.036 \pm 0.118$ & $p<0.01$ \\
Striated muscle & Omega-3 & $0.106 \pm 0.012$ & \\
& Salina & $0.082 \pm 0.011$ & \\
& L-Ala-Gln & $0.231 \pm 0.057$ & $p<0.05$ \\
& Omega-3 & $0.459 \pm 0.119$ & \\
\hline
\end{tabular}

Values expressed as Mean \pm SEM. $p<0.01, p<0.05$, L_Ala-Gln and Omega-3 groups are significantly different from control group by Mann-Wittney test. $\bar{n} s=$ non-significant

\section{Discussion}

There are some differences between the metabolism of glucose in muscle and in liver cells. Glucose can only enter in muscle cells through the action of insulin. However, glucose enters the hepatocyte by facilitated diffusion. No insulin action is required. In healthy individuals the liver is the organ responsible for controlling blood glucose levels, by withdrawing it from circulation when those levels are increased. Glucokinase, an enzyme found in the liver is responsible for phosphorylation of glucose as soon as it enters the cell. Another enzyme (glucose-6phosphatase) promotes the release of glucose into the circulation when needed. This enzyme is not present in striated muscle ${ }^{4}$. Glycolysis due to muscle activity results in large amounts of lactate. This lactate cannot be used by the muscle for gluconeogenesis because this tissue lacks the gluconeogenic glucose-6-phosphatase enzyme. The lactate produced is transported by the circulation to the liver and converted into glucose, returning to the muscle tissue via circulation (Cori cycle). Moreover, muscle cells are the source of large amounts of alanine, from the degradation of proteins and the transamination of pyruvate. Alanine is also transported to the liver and converted to glucose (gluconeogenesis). This fresh glucose is returned to the muscle via circulation and it may be stored or used as an energy source (alanine cycle) ${ }^{4}$.

Glycogen is present in liver and muscle cells. Nevertheless, glycogen metabolism is different in liver and muscle. The release of glycogen in the liver is stimulated by low levels of glycemia. Liver glycogen is converted to glucose-6-phosphate and hydrolyzed to yield glucose. The release of glucose from the liver by glycogenolysis replenishes the pool of blood glucose. In the muscle, glucose-6-phosphate obtained by the degradation of glycogen enters the the glycolytic pathway before it is exported to the blood stream ${ }^{4}$.

In the present study the pre-treatment with intravenous L-Ala-Gln induced a significant increase of pyruvate, lactate, and ketone bodies concentrations in the liver, blood and muscle 48 hours after induction of sepsis in G-2 compared with the control group (G-1) (Table 1). These changes reflect increased hepatic uptake of pyruvate and lactate from the peripheral tissues due by the higher supply of these compounds to the blood associated with an increased synthesis of these metabolites in peripheral tissues (increased anaerobic glycolysis). These finding signals to an increase in Cori cycle as lactate concentrations are increased both in muscle and liver tissues.

Increased concentrations of ketone bodies reflect greater ketogenesis induced by L-Ala-Gln. Increased ketogenesis provides greater production and supply of ketone bodies into the bloodstream and peripheral tissues. Indeed, the increased concentration of ketone bodies in muscle in G-2 group points to a higher uptake of this metabolite by the muscle due the increased supply of this metabolite by the liver and its increased availability in the blood. The hyperketonemia (Table 4) as well as the hyperglycemia (Table 3 ) are probably due to the alleged drop in insulin levels due to the large consumption of glucose related to a septic state where there is an increased demand for energy.

In this study the pre-treatment with intravenous L-Ala-Gln induced a significant increase in liver and blood concentrations of glucose when compared with the control group. These findings suggests that the hyperglycemia observed is due to the increased gluconeogenesis induced by L-Ala-Gln, as there are increased concentrations of lactate and pyruvate, due to increased peripheral glycolysis.

There was a significant decrease muscle concentration of glucose in G-2 compared with G-1 control group (Table 3). This suggests that there was a higher consumption of glucose at the peripheral level, since it is a large supply of circulating lactate and pyruvate, as products of glycolysis.

There was a significant increase in the concentrations of pyruvate and lactate levels in liver and muscle in group G3, treated with $\omega-3$ compared to G-1 (Tables 1-2). This corresponds to a 
higher uptake of these metabolites by the liver - the central organ of metabolism of carbohydrates - from the blood, with increased peripheral glycolysis. These results points to increased hepatic gluconeogenesis induced by $\omega-3$.

The provision of $\omega-3$ induced significant increases in the concentrations of ketone bodies in the liver in G-3 compared with G-1 in 48 hours after sepsis (Table 4). These changes occurred in the liver but not in peripheral tissues. This is consistent with increased ketogenesis induced by $\omega-3$. As there was no increase in concentrations of circulating ketone bodies in peripheral tissues (muscle) is likely that they are being consumed by the liver (local consumption). This also reflects a very pronounced fasting effect in this stage of sepsis possibly reflecting increased ketogenesis.

The main signal for the formation of ketone bodies is the decline in insulin concentrations. Hence it is possible that $\omega-3$ group has generated a significant drop in insulin which would have signaled to the liver to increase the release of ketone bodies. It is assumed that the $\omega-3$ induced ketogenesis, probably by signaling via insulin.

\section{Conclusion}

Considering the results presented here, It is concluded that the pre-administration of L-Ala-Gln or $\omega-3$ to rats subjected to sepsis resulted in similar metabolic changes, by rising glycolysis in peripheral tissues and stimulating hepatic gluconeogenesis and ketogenesis, resulting in increased energy supply to septic rats.

\section{References}

1. Cuthbertson DP. Second annual Jonathan E. Rhoads Lecture. The metabolic response to injury and its nutritional implications: retrospect and prospect. JPEN J Parenter Enteral Nutr. 1979;3(3):108-29.

2. Frayn KN. Hormonal control of metabolism in trauma and sepsis. Clin Endocrinol (Oxf). 1986;24(5):577-99.

3. Rennie MJ, Maclennan PA, Hundal HS, Weryk B, Smith K, Taylor PM, Egan C, Watt PW. Skeletal muscle glutamine transport, intramuscular glutamine concentration and muscle protein turnover. Metabolism. 1989;38(8 Suppl 1):47-51.

4. Wilmore DW. Carbohydrate metabolism in trauma. Clin Endocrinol Metab. 1976;5(3):731-45.
5. Beisel WR, Wannemacher RW. Gluconeogenesis, ureagenesis and ketogeneses during sepsis. JPEN J Parenter Enteral Nutr. 1980;4:277-85. 6. Bone RC. The pathogenesis of sepsis. Ann Intern Med. 1991;115(6):457-69. 7. Wannemacher RW, Beal EA, Canonico PG, Dinterman RE, Hadick CL, Nelfeld HA. Glucose and alanine metabolism during bacterial infection in rats and Rhesus monkeys. Metabolism. 1980;29:201-12.

8. Wilmore DW. Shabert JK. Role of glutamine in immunologic responses. Nutrition. 1998;14(7-8):618-26.

9. Alves MA, Guimarães SB, Dias DA, Vasconcelos PRC, Coelho VPM, Vasconcelos PRL. Effects of L-alanyl-glutamine upon the blood and kidney biochemical parameters in the rat hind limb model of ischemia/ reperfusion. Acta Cir Bras. 2005;20(6):445-9.

10. Kiyomi T, Junya M, Takeshi M, Ritsuo H, Takashi O, Hidetaka K. Hypertriglyceridemic acute pancreatitis during pregnancy: Prevention with diet therapy and omega-3 fatty acids in the following pregnancy. Nutrition. 2009;25:1094-7.

11. Welbourne TC, Joshi S. Interorgan glutamine metabolism during acidosis. JPEN J Parenter Enteral Nutr. 1990;14(4 Suppl):77S-85S.

12. Alexander JW. Immunonutrition: The role of omega-3 fatty acids. Nutrition. 1998;14:627-33.

13. Simopoulos AP. Omega-3 fatty acids in inflammation and autoimmune diseases. J Am Coll Nutr. 2002;21(6):495-505.

14. Singer P, Shapiro H, Theilla M, Anbar R, Singer J, Cohen J. Anti-inflammatory properties of omega-3 fatty acids in critical illness: novel mechanisms and an integrative perspective. Intensive Care Med. 2008;34(9):1580-92.

15. Heath DF, Threlfall CJ. The interaction of glycolysis, gluconeogenesis and the tricarboxylic acid cycle in rat liver in vivo. Biochem $\mathrm{J}$. 1968;110(2):337-62.

16. Vasconcelos PRL, Kettlewell MGW. Williamson DH. Time course of changes in hepatic metabolism in response to sepsis in the rat: Impairment of gluconeogenesis and ketogenesis in vitro. Clin Sci. 1987;72:683-91.

17. Hohorst HJ, Kreutz FH, Buecher T. On the metabolite content and the metabolite concentration in the liver of the rat. Biochem Z. 1959;332:18-46. 18. Williamson DH, Mellanby J, Krebs HA. Enzymic determinations of the $\mathrm{D}(-)$-beta-hydroxybutyric acid and acetoacetic acid in blood. Biochem J. 1962;82:90-6.

19. Hohorst HJ. D-Glucose-6-phosphate and D-fructose-6-phosphate: determination with glucose-6-phosphate dehydrogenase and phosphoglucose isomerase. In: Bergmeyer HU. Methods of enzymatic analysis. London: Weinheim/Academic Press; 1963. p. 134-8.

20. Slein MW. Determination with hexokinase and glucose-6-phosphate dehydrogenase. In: Bergmeyer HU. Methods of enzymatic analysis. London: Weinheim/Academic Press; 1963. p. 117-23.

Conflict of interest: none Financial source: none

\section{Correspondence:}

José Ivamberg Nobre de Sena

Av. Augusto dos Anjos, 220/Bloco 8/401

60.720-600 Fortaleza - CE Brasil

ivambergsena@bol.com.br

Received: March 10, 2010

Review: May 17, 2010

Accepted: June 21, 2010

\section{How to cite this article}

Sena JIN, Guimarães SB, Vasconcelos PRL. Metabolic changes induced by pre-administration of L-alanyl-glutamine and Omega-3 in Wistar rats subjected to sepsis. Acta Cir Bras. [serial on the Internet] 2010 Nov-Dec;25(6). Available from URL: http://www.scielo.br/acb

*Color figures available from www.scielo.br/acb 